УДК 172.1

DOI: $10.32837 /$ apfs.v0i24.863

Олександр Олександрович Соколовський

аспірант кафедри філософії

Національний університет «Одеська юридична академія», м. Одеса, Україна

\title{
ПРОФЕСІЙНА ПРАВОСВІДОМІСТЬ ЯК ЯКІСНО НОВИЙ РІВЕНЬ СПРИЙНЯТТЯ ПРАВОВОЇ ДІЙСНОСТІ
}

Анотація. Стаття присвячена аналізу професійної правосвідомості як важливого чинника формування та існування правової дійсності, охарактеризовані іiі особливості, визначені можливості взаємодії з іншими формами суспільної свідомості. Обгрунтовано, що в сучасних умовах розвитку українського суспільства особливого значення набуває зміцнення законності, ефективне правове регулювання суспільних відносин, становлення правової свідомості, а особливо професійної, необхідної для протікання правових процесів в державі.

На основі знань щодо структури правосвідомості загалом, встановлені ключові, притаманні лише цьому рівню правосвідомості елементи. Професійна правосвідомість повинна розглядатися як форма групової свідомості та як своєрідний рівень сприйняття правової дійсності, зворотного впливу на неї. Предметом цієї правосвідомості виступають будь-які правові явища, а також суспільні відносини, що потребують відповідного регулювання. Суб'єктом такої правосвідомості $\epsilon$ особа, яка професійно займається юридичною діяльністю.

Визначені ключові характеристики, якими повинен володіти правознавець, носій професійної свідомості, для досягнення їі цілей в суспільстві та державі. Проаналізована комунікативна складова професійної правосвідомості, яка дозволяє обмінюватися юридично значущою інформацією суб'єктам правотворчих та правореалізаційних відносин. Принципове значення має сприйняття юристом правової дійсності, його готовність до вирішення правових завдань.

Проаналізовані форми взаємодії професійної правосвідомісті 3 політичною, моральною, науковою, релігійною й естетичною свідомістю. Особливої уваги заслуговують форми впливу професійної правосвідомості на правотворчу та правореалізаційну діяльність, iii можливості щодо забезпечення прав та встановлення обов'язків учасників правовідносин, що володіють буденною правовою свідомістю та потребують роз'яснення, тлумачення різноманітних положень законодавчих актів.

Ключові слова: професійна правосвідомість, право, суб'єкт правосвідомості, правові знання, форма правосвідомості.

Постановка проблеми. Сучасний розвиток суспільства i держави супроводжується кардинальними, швидкоплинними змінами, які мають безпосередній вплив на правову систему загалом. Період реформ характеризується послабленням соціальних зв'язків, суперечностями суспільної свідомості, зниженням рівня громадського порядку, зростанням злочинності. Відповідно до цього, особливого значення набуває зміцнення законності, ефективне правове регулювання суспільних відносин, становлення правової свідомості, а особливо професійної, необхідної для протікання правових процесів в державі. Професійна свідомість правознавців, осіб, компетентних в правовій сфері, відрізняється від правосвідомості інших груп населення за обсягом і глибиною політико-правових знань, навичок і умінь аналізувати проблеми, вирішувати поставлені життям юридичні завдання. Отже, беззаперечною є актуальність дослідження природи, особливостей, місця і ролі в практиці такого специфічного явища, як професійна правосвідомість, що $є$ суб'єктивною основою права, правопорядку. 
Аналіз останніх досліджень і публікацій. Питання пов'язані із формуванням та функціонуванням професійної правової свідомості дедалі частіше являються предметом вивчення науковців. Незважаючи на це, стан дослідження цих явищ не можна назвати задовільним. Поясненням цьому є складність правосвідомості, особливо професійної, i, відповідно, диференціація поглядів вчених стосовно ії поняття, особливостей, функцій, форм впливу на правотворчу і правореалізаційну діяльність, на функціонування суспільних та державних інститутів загалом. Грунтовні думки відносно таких спірних та дискусійних питань можна зустріти у працях О.Ф. Скакун, І. О. Ільїна, О. Г. Данильяна, Б. А. Кістяківського, В. В. Мужа, Ю. Ю. Калиновського, М. О. Бердяєва, В. П. Сальникова, І. Ф. Надольного, Г. П. Клімовой, Ю. М. Грошевого, В. М. Сирих, Г. С. Остроумова.

Метою статті $є$ теоретичний аналіз явища професійної правосвідомості як особливого рівня сприйняття правової дійсності та репрезентація позитивних наслідків даного дослідження у перенесенні їх в практичну площину суспільного життя.

Виклад основного матеріалу. Професійна правосвідомість являється формою групової правосвідомості, яка характеризується саме глибиною, чіткістю, обширністю сприйняття правової дійсності та вираженням зворотного впливу на неї. О. Ф. Скакун визначає професійну свідомість правознавців як науково обгрунтовану струнку систему правових знань, переконань і почуттів осіб, які мають вищу юридичну освіту i використовують отримані спеціальні знання, вміння, навички у всіх правових формах здійснення функцій держави [7, с.99]. Предметом цієї правосвідомості виступають будь-які правові явища, а також суспільні відносини, що потребують відповідного регулювання. Суб’єктом такої правосвідомості є особа, яка професійно займається юридичною діяльністю. Та навіть таку основоположну та визначальну категорію не можна визначати цілком монолітною. Внутрішньо іï можна диференціювати на окремі різновиди, найбільш визначними з яких є правосвідомість слідчих, прокурорів, суддів, адвокатів [1, с.31]. Такий видовий поділ визначається особливостями рольової поведінки працівників різних юридичних служб, тобто специфікою виконуваних службових функцій та стереотипів, що склалися відповідно до методів та способів оцінки правової дійсності в процесі їх діяльності. Використання терміну професійна свідомість для характеристики правової свідомості представників інших професій, факту усвідомлення людиною своєї приналежності до певної сукупності соціальних груп, допустимо лише в широкому сенсі цього терміна, оскільки в даному випадку конкретизація особливостей свідомості особи буде відбуватися відповідно до професійної спрямованості, якою характеризується її діяльність.

Ціннісно-нормативна система правознавця найбільш чітко проявляється у правосвідомості. Відповідно до цього, окреслюється його здатність до перенесення теоретичних знань та навичок у практичну сферу, вироблення системи прийомів та способів для виконання цілого спектру юридично значущих дій, моделювання можливих життєвих ситуацій задля підтримання правопорядку. Така правосвідомість має визначальне значення для конкретизації позитивних правових норм відносно до життєвої ситуації, в якій вони використовуються. Від цього різновиду правосвідомості залежить стиль юридичної практики, формальне або неформальне ії здійснення.

У практичній діяльності юрист, по суті, не замислюється над вибором тих чи інших професійних прийомів, оскільки у багатьох випадках він спирається на власний досвід. Право діє, здійснює свої органічні функції лише у тісній співпраці 3 правосвідомістю. Без розвиненої професійної правової свідомості, здатної зрозуміти норми права, перевести їх на рівень конкретних правових рішень, а потім і юридично значущих дій, право позбавляється свого соціального значення, перетворюється на «мертве право» [9, с. 411]. Тобто професійна правова свідомість спонукає суб'єкта, що 
наділений нею, до підсвідомого аналізу своїх дій та їх правових наслідків. Відповідно до такого осмислення, юрист робить чіткий вибір, приймає конкретні рішення в окремо взятих ситуаціях. Крім того, це шлях до самовдосконалення правника, можливість досягнення ним мети своєї діяльності.

Визначаючи нашу поведінку, правові норми, однак, самі не $\epsilon$ чимось зовнішнім, оскільки вони живуть насамперед у свідомості та $є$ внутрішніми елементами нашого духу. Тільки після вираження в статтях законів або застосування в житті, вони набувають своє зовнішнє існування. Попри це, ігноруючи внутрішнє, інтуїтивне право, інтелігенція вважала правом лише ті зовнішні, мертві норми, які так легко вкладаються в статті та параграфи писаного закону [3, с. 373]. Професійна правосвідомість характеризується не лише формальним застосуванням юридичних норм, а розумінням мети, цілей, завдань, принципів права загалом і правових норм як його елементів. На відміну від масової правосвідомості, знання юристів характеризуються строгою конкретністю і деталізацією - вони не можуть бути лише правовими уявленнями. Важливим $є$ розуміння обставин, за яких правова норма набирає чинності, прогнозування правових наслідків, які настають при наявності передбачених нормами умов.

Безсумнівною є і комунікативна складова професійної правосвідомості, яка дозволяє обмінюватися юридично значущою інформацією суб'єктам правотворчих та правореалізаційних відносин. Важливо зазначити, що професійна свідомість має й емоційний характер. Вона показує рівень правознавця-професіонала у порівнянні з його колегами, наявність у нього досвіду, практичних навичок, професійно-моральних якостей. Принципове значення має сприйняття юристом правової дійсності, його готовність до вирішення правових завдань. Набувають яскравого забарвлення вольові зусилля суб'єкта такої свідомості, його старання або, на противагу, байдуже ставлення до правових процесів, до яких він має безпосереднє відношення. Все це формує громадську думку про юриста, яка може бути як реакцією на дії конкретного правознавця в окремо визначеній ситуації, так і уявленням про професію загалом.

Вищезазначена інформація надає можливість визначити ключові характеристики професійної правосвідомості юристів:

- вона передбачає шанобливе ставлення до права, закону, до практики його застосування;

- присутнє переконання в необхідності неухильного дотримання букви закону;

- поряд з дотриманням норм позитивного закону, обов'язковим $є$ розуміння змісту права, причин, мотивів та наслідків його дії;

- обумовлює готовність до здійснення активних правомірних дій із захисту прав i свобод громадян;

- здійснює значний вплив на всі сфери життєдіяльності суспільства;

- сукупність професійної правосвідомості та поведінки юриста утворює єдину систему юридичного буття.

Професійну правосвідомість слід аналізувати також з урахуванням особливостей структури, яка має визначальне значення для встановлення іії цілей та безпосереднього змісту. Слід виходити з того, що професійна правосвідомість відрізняється від інших видів не безпосередніми елементами, 3 яких вона складається, а їх якісною характеристикою.

Аналіз різних підходів до структури правової свідомості дозволяє стверджувати, що максимально повно особливості професійної свідомості юристів можна простежити, орієнтуючись на структуру, побудовану на основі принципу єдності свідомості та діяльності, що враховує рівні психологічної структури особистості, а також мотивацію

(C) О. О. Соколовський, 2019 
діяльності. Такий підхід дозволяє виділити наступні елементи професійної правової свідомості:

- сфера спрямованості, що складається 3 емоційно-образного, логіконормативного, принципово-вольового блоків;

- сфера досвіду соціально-правової активності;

- сфера мотивації поведінки в галузі права, що підрозділяється на мотивацію позитивну та негативну.

Соціальний процес формування права повністю пронизаний професійною правовою свідомістю. У найзагальнішому вигляді це виражається у зародженні в суспільстві та вираженні у встановленій формі правотворчого інтересу та підтримання такої ініціативи компетентними суб'єктами правотворчості та, відповідно, створення на основі цього нової норми права.

Професійна правова свідомість бере участь у становленні правових ідей, поглядів, що виражають необхідність внесення змін у процес правового регулювання суспільних відносин. Така участь може відбуватися як безпосередньо, тобто у формі публікацій, виступів, звернень, так і опосередковано через популяризацію конкретних правових ідей та юридично значущих рішень. Правосвідомість певною мірою випереджає позитивне право, $\epsilon$ його безпосереднім ідейним джерелом, передує нормотворчості. Але вона діє й «паралельно» 3 правом, а також «після» нього у тому сенсі, що визначає зміни й перспективи розвитку права; безпосередньо впливає на процес і результати правотворчості [8, с. 99].

Базовим елементом в процесі творення права є системне, комплексне бачення юристом мети права, практики його реалізації. Правосвідомість бере участь у розробці проектів нормативно-правових актів, виборі виду правового документа, обговоренні концепції закону, окресленні системи відносин, що будуть регулюватися відповідною правовою нормою або сукупністю спеціалізованих норм. На даному етапі професійне використання правової мови, категорій, понять забезпечує логічність, об'єктивність, обгрунтованість, доступність нормативно-правового матеріалу. Таким чином активна позиція правознавців повинна впливати на політику держави відносно регулювання різноманітних суспільних процесів.

Протягом реалізації правових норм професійна правова свідомість є необхідною суб'єктивною основою для правозастосовної, правозахисної, а також консультативної діяльності. Чинниками для успішного здійснення такої активності є правові знання, ціннісні орієнтації, готовність юриста діяти відповідно до конкретної життєвої ситуації. Як наслідок високого рівня розвитку професійної свідомості нівелюється дефіцит правосвідомості суб'єктів, які не можуть самостійно дотримуватися правової процедури, оформлювати нормативні документи, а отже відстоювати свої законні інтереси, захищати права, дотримуватися обов'язків стосовно інших учасників юридично значущих відносин. Закон гарантує дотримання прав і обов'язків індивіда, а в залежності від своїх інтересів люди формують уявлення про зміст прав і обов'язків, а також про їх співвідношення. Різниця у поглядах породжує суперечності, які знімаються силою авторитету влади, інтересом більшості або через правовий діалог між суб'єктами відносин задля досягнення консенсусу. Чим більша питома вага третього способу вирішення конфлікту, тим більш розвиненим, людяним i перспективним є дане суспільство [5, с. 380]. Саме тому професійна правосвідомість, знаходячи своє вираження у компетентній юридичній діяльності, робить можливим розуміння суб'єктами правових цінностей, встановлення їх орієнтацій та формування у них конкретних правових установок.

Відзначаючи якісні зміни, що відбуваються у суспільній свідомості, зокрема правовій, разом з тим не слід перебільшувати їі роль у формуванні правової культури

(c) О. О. Соколовський, 2019 
населення. При всіх прогресивних змінах ій властива обмеженість, яка не дозволяє досконало відображати об’єктивну правову дійсність. Ця можливість $є$ у професійної правової свідомості, якісного рівня відображення правової дійсності [4, с. 504]. Особливо чітким в даному контексті $є$ зв'язок з ідеями справедливості та законності, орієнтованість на реалізацію правових норм, компетентність, високий рівень, глибина, спеціалізація, деталізація правових знань та умінь. Всі ці характеристики відносяться до професійної правосвідомості, на відміну від масової, буденної, яка властива більшості членів суспільства.

Але не слід забувати, що професійна правосвідомість належить правознавцям, являється складовою частиною, елементом суспільної правової свідомості, тією рушійною силою, яка повинна направляти буденну свідомість на шлях прогресивного розвитку та вдосконалення. Вона акумулює сукупність психологічних властивостей особистості, які детермінують правову спрямованість поведінки індивіда законослухняну або протиправну. Суспільна правосвідомість являє собою інтеграцію індивідуальної правосвідомості членів даного суспільства, їх груп, зокрема об'єднань правознавців, проявляється як соціально-психологічний феномен, що впливає на формування індивідуальної правосвідомості членів суспільства. В даному випадку на перше місце виходить двосторонній вплив індивідуальної свідомості компетентних юристів та суспільної правосвідомості загалом одна на одну.

Також необхідним є встановлення співвідношення та розмежування понять професійної правосвідомості й спеціалізованої правосвідомості. Зустрічаються випадки ототожнення даних категорій. Такі порівняння не можна визнати повністю коректними в силу різних критеріїв, які використовуються для їх виділення. Якщо для професійної правосвідомості головним $є$ характер і зміст виконуваної роботи, то спеціалізована правосвідомість має дещо іншу характеристику, не пов'язану 3 професійною приналежністю до тієї чи іншої групи i, відповідно, вона не має тих якісних ознак, які виводять іï на окремий рівень. Носіями спеціалізованої правосвідомості $є$ представники окремих професій, але без виділення та розмежування їх внутрішньої якісної структури, як у випаду з професійною правосвідомістю.

Професійна правосвідомість взаємодіє з політичною, моральною, науковою, релігійною й естетичною свідомістю. Характеристика іï взаємодії з іншими формами суспільної свідомості є різною залежно від того, у якій сфері юридичної практики вона відбувається - у правотворчості чи правозастосуванні. Та все ж, основоположним регулятором, поряд із правовими нормами, який безпосередньо і цілеспрямовано впливає на свідомість правознавця-професіонала $\epsilon$ норми моралі, які виконують особливу роль у формуванні духовного світу особистості та суспільства загалом. Право здатне компенсувати відсутність у моралі, як внутрішнього імперативу, механізму примусу, оскільки воно є імперативом зовнішнім. Ставлення до права можливе лише завдячуючи моральному змістові його норм, що регулюють статус суб'єктів правовідносин. Правосвідомість виступає вираженням розуміння категорій прав i обов'язків юридичного, а також, в більшості випадків, і морального характеру, які розкриваються в оцінювальних поняттях: законного і незаконного, справедливого i несправедливого, морального i юридично обгрунтованого, виправданого i навпаки [6, с. 65].

Правова і моральна свідомість відповідають визначеним потребам спільноти правознавців конкретної країни, оскільки слугують регуляторами відносин у колективі, погоджують інтереси особистості з інтересами об'єднань і суспільства в цілому. Діяльність юриста здійснюється у сфері життєво важливих благ людей, знаходиться перед необхідністю приймати ключові рішення, які пов'язані зі складними моральними ситуаціями.

(C) О. О. Соколовський, 2019 
Максимально високий рівень відповідності правовій нормі, критичне ставлення до неї, розуміння іiі користі, необхідності застосування, звичка дотримуватися закону, стійке позитивне ставлення до права являються визначальними характеристиками розвиненої професійної правосвідомості. Досягнення такого рівня правосвідомості полягає в накопиченні, передачі й засвоєнні знань, принципів і норм права, передбачає наявність належної теоретичної бази, оволодіння вміннями й навичками реалізації права. Проте, правосвідомість формується не лише «знаннями» та «мисленням», але й уявою, і волею, і відчуттями, і всією людською душею. Недостатньо лише знати свої права, обов'язки, заборони: бувають люди, які прекрасно володіють цими знаннями, але постійно зловживають ними для того, щоб перевищити свої повноваження, звузити коло своїх обов'язків та зняти з себе певні заборони [2, с. 81]. Необхідно не лише знати все це, а й визнавати відповідний зміст цих знань в порядку самоусвідомлення i, визнаючи, мати достатню силу волі для того, щоб дотримуватися визнаного.

Висновок. Професійна правосвідомість є одним 3 чинників, що сприяє побудові правової держави з розвиненими інститутами громадянського суспільства. Суб'єктом такої свідомості є особа, що здобула вищу юридичну освіту, може визначати актуальні правові проблеми в суспільстві та пропонувати шляхи їх вирішення через компетентну діяльність у вигляді правотворчості та правореалізації. Розвинена професійна правосвідомість гармонійно функціонує в системі інших форм суспільної свідомості, особливо яскраво взаємодіючи 3 моральною свідомістю, виступаючи регулятором поведінки окремих осіб, визначених спільнот, суспільства загалом. Існування розвиненої професійної свідомості $є$ основою для формування і функціонування здорової, недеформованої правосвідомості суспільства у державі.

\section{СПИСОК ВИКОРИСТАНИХ ДЖЕРЕЛ}

1. Данильян О. Г., Герасіна Л. М., Дзьобань О. П. Правосвідомість і правова культура як базові чинники державотворчого процесу в Україні : монографія / Л. М. Герасіна, О. Г. Данильян, О. П. Дзьобань та ін. - Х. : Право.-2009. - 352 с.

2. Ильин И. А. О сущности правосознания. Собрание сочинений / И. А. Ильин. - М. - 1994. — Т.4. - 234 с.

3. Кистякивский Б. А. Философия и социология права / Б. А. Кистякивский. - СПб. - 1998. - 402 с.

4. Надольний І. Ф. Філософія: навчальний посібник / І. Ф. Надольний. — К.: Вікар. - 1997. - 584 с.

5. Обухов В. Л., Солонин Ю. Н., Сальников В. П. Философия и методология познания: Учебник для магистров и аспирантов / В. Л. Обухов, Ю. Н. Солонин, В. П. Сальников. - СПб. - 2003. - 560 с.

6. Остроумов Г. С. Правовое осознание действительности / Г. С. Остроумов. - М.: Наука. — 1969. - 173 с.

7. Скакун О. Ф. Правосознание в правовой системе Украины: эволюционные особенности, профессиональное и региональное измерение / О. Ф. Скакун // Право Украины. - 2013. - № 1. - С. 93-116

8. Скакун О. Ф. Теорія права і держави: Підручник / О. Ф. Скакун. - К.: Алерта. - 2009. -520 с.

9. Сырых В.М. Социология права: Учеб. пособие / В. М. Сырых. - М.: Юрид. Дом "Юстицинформ".— 2001. — 446 с. 


\title{
ПРОФЕССИОНАЛЬНОЕ ПРАВОСОЗНАНИЕ КАК КАЧЕСТВЕННО НОВЫЙ УРОВЕНЬ ВОСПРИЯТИЯ ПРАВОВОЙ ДЕЙСТВИТЕЛЬНОСТИ
}

\begin{abstract}
Аннотация. Статья посвящена анализу профессионального правосознания как важного фактора формирования и существования правовой действительности. Охарактеризованы ее особенности, определены возможности взаимодействия с другими формами общественного сознания. На основе знаний о структуре правосознания в целом, установлены ключевые, присущие только этому уровню правосознания элементы. Профессиональное правосознание должно рассматриваться как форма группового сознания и как своеобразный уровень восприятия правовой действительности, обратного влияния на нее. Определены ключевые характеристики, которыми должен обладать правовед, носитель профессионального сознания, для достижения его целей в обществе и государстве. Особого внимания заслуживают формы влияния профессионального правосознания на правотворческую и правореализационную деятельность, ее возможности по обеспечению прав и установлению обязанностей участников правоотношений, обладающих повседневным правовым сознанием и требующим разъяснения, толкования различных положений законодательных актов.
\end{abstract}

Ключевые слова: профессиональное правосознание, право, субъект правосознания, правовые знания, форма правосознания.

\section{PROFESSIONAL LEGAL CONSCIOUSNESS AS A QUALITATIVELY NEW LEVEL OF PERCEPTION OF LEGAL REALITY}

Abstract. The article deals with the analysis of professional justice as an important factor in the formation and existence of legal reality, describes its features, identifies opportunities for interaction with other forms of social consciousness. It is substantiated that in the current conditions of development of Ukrainian society the strengthening of legality, effective legal regulation of social relations, the formation of legal consciousness, and especially the professional, necessary for the course of legal processes in the state, becomes of particular importance.

Based on the knowledge of the structure of justice in general, key elements that is specific to this level of legal consciousness are identified. Professional legal consciousness should be seen as a form of group of legal consciousness and as a kind of perception of legal reality, a reverse effect on it. The subject of this legal consciousness are any legal phenomena, as well as public relations that need to be regulated. The subject of such legal consciousness is a person who is professionally engaged in legal activities.

There have been identified the key characteristics that a legal practitioner, a carrier of professional consciousness, must have in order to achieve his or her goals in society and the state. The communicative component of professional justice is analyzed, which allows the exchange of legally relevant information to the subjects of law-making and legal relations. The lawyer's perception of legal reality, his willingness to solve legal problems is of fundamental importance.

The forms of interaction of professional legal consciousness with political, moral, scientific, religious and aesthetic consciousness are analyzed. Particularly noteworthy are the forms of influence of professional justice on law-making and law-enforcement activities, its capacity to secure the rights and responsibilities of participants in legal relationships who have a common legal consciousness and who need clarification, interpretation of various provisions of legislative acts.

Keywords: professional legal consciousness, law, subject of legal consciousness, legal knowledge, form of legal consciousness. 